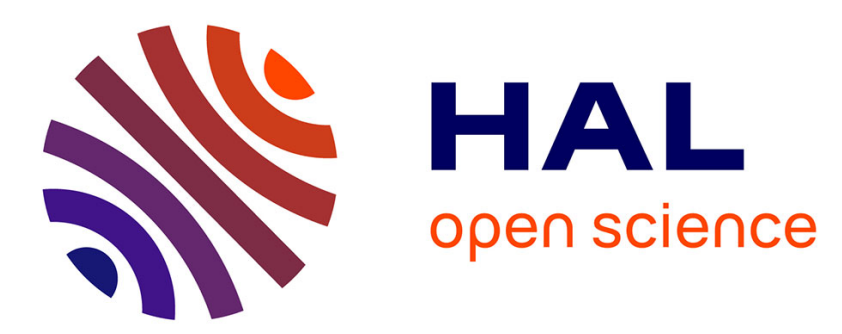

\title{
Long-term earthquake triggering in the Southern and Northern Apennines
}

E. Mantovani, M. Viti, D. Babbucci, D. Albarello, N. Cenni, A. Vannucchi

\section{To cite this version:}

E. Mantovani, M. Viti, D. Babbucci, D. Albarello, N. Cenni, et al.. Long-term earthquake triggering in the Southern and Northern Apennines. Journal of Seismology, 2008, 14 (1), pp.53-65. 10.1007/s10950008-9141-z . hal-00478441

\section{HAL Id: hal-00478441 \\ https://hal.science/hal-00478441}

Submitted on 30 Apr 2010

HAL is a multi-disciplinary open access archive for the deposit and dissemination of scientific research documents, whether they are published or not. The documents may come from teaching and research institutions in France or abroad, or from public or private research centers.
L'archive ouverte pluridisciplinaire HAL, est destinée au dépôt et à la diffusion de documents scientifiques de niveau recherche, publiés ou non, émanant des établissements d'enseignement et de recherche français ou étrangers, des laboratoires publics ou privés. 


\title{
Long-term earthquake triggering in the Southern and Northern Apennines
}

\author{
E. Mantovani • M. Viti · D. Babbucci • \\ D. Albarello • N. Cenni • A. Vannucchi
}

Received: 11 December 2007 / Accepted: 18 September 2008 / Published online: 21 October 2008

(C) Springer Science + Business Media B.V. 2008

\begin{abstract}
We argue that the study of long-range interaction between seismic sources in the periAdriatic regions may significantly contribute to estimating seismic hazard in Italy. This hypothesis is supported by the reconstruction of the geodynamic and tectonic settings in the Central Mediterranean region, the space-time distribution of major past earthquakes, and the quantification of post-seismic relaxation. The most significant evidence of long-distance interaction is recognized for the Southern Apennines, whose major earthquakes have almost regularly followed within a few years the largest events in the Montenegro-Albania zone since 1850. Statistical analyses of the post-1850 earthquake catalogues give a probability of about $10 \%$ that a major event
\end{abstract}

E. Mantovani · M. Viti · D. Babbucci .

D. Albarello · A. Vannucchi

Department of Earth Sciences,

University of Siena, Siena, Italy

E. Mantovani $(\varangle)$

Dipartimento di Scienze della Terra,

Università degli Studi di Siena,

Via Laterina, 8-53100 Siena, Italy

e-mail:mantovani@unisi.it

N. Cenni

Department of Physics,

University of Bologna, Bologna, Italy in the Southern Apennines is not preceded by the occurrence of a strong event in the Southern Dinarides-Albanides within 3-5 years. Conversely, the probability of false alarms is relevant (50\% within 3 years, $33 \%$ within 5 years). Northward, the tectonic setting and some patterns of regularity seen in major events suggest that the seismic activation of the main transtensional decoupling shear zones in the Central Apennines should influence the probability of major earthquakes in the Northern Apennines.

Keywords Seismotectonics - Apennines • Earthquake triggering $\cdot$ Post-seismic relaxation

\section{Introduction}

It is largely believed that earthquakes are not randomly distributed in time and space but, rather, are related to each other (e.g., Anderson 1975; Marsan et al. 2000; Marsan and Bean 2003). Consequently, current statistical earthquake forecasting that neglects the kinematic/tectonic relationship between events can hardly provide reliable information on the time-space distribution of future major earthquakes, as shown by several cases in the world (e.g., Scholz and Gupta 2000; Mulargia and Geller 2003 and references therein). This neglect has stimulated the 
investigation of deterministic approaches, which take into account possible long-range interactions between seismic sources. A basic requisite for this kind of attempt is a deep knowledge of the geodynamic setting and ongoing tectonic processes in the study area. In this work, exploiting the information we have previously obtained about the Central Mediterranean geodynamics (e.g., Mantovani 2005; Mantovani et al. 2006, 2007a, b; Viti et al. 2006), the possibly related seismicity regularity patterns (Mantovani and Albarello 1997; Mantovani et al. 1997), and the role of postseismic relaxation in the peri-Adriatic regions (Viti et al. 2003; Cenni et al. 2008), we argue that long-term earthquake prediction may be feasible in the Southern and Northern Apennines. The next section provides a synthesis of the proposed kinematic/tectonic context in the Central Mediterranean region and its possible connection with the time-space distribution of major earthquakes. In Section 3, we discuss the almost regular correspondence between major earthquakes of Southern Apennines and Southern DinaridesAlbanides zones and analyze the statistical significance of the observed correspondence in order to investigate the possible exploitation of that phenomenon for long-term earthquake prediction. In Section 4, we point out some regular patterns of major earthquakes, which suggest the existence of long-range interaction between Central Apennine and Northern Apennine seismic sources, in agreement with the proposed tectonic interpretation.

\section{Tectonics and seismicity in the Central Mediterranean region}

The kinematic pattern and tectonic setting we propose for the Central Mediterranean area is sketched in Fig. 1. This synthesis may account for the observed post-Middle Pleistocene deformation pattern in the study area (e.g., Viti et al. 2006) and may be also reconciled with the previous evolution of the Mediterranean region (e.g., Mantovani 2005; Mantovani et al. 2006, 2007a, b). The proposed scheme provides that seismotectonic activity in the Apennines, mainly concen- trated in the axial part of the belt, where a system of extensional to sinistral transtensional faults is recognized, is driven by the oblique divergence between the external sector of the belt, moving in closer connection with the Adriatic plate and the almost fixed internal belt (Viti et al. 2006). A more detailed reconstruction of the tectonic setting in the Apennine belt is shown in Fig. 2.

In the Southern Apennines, the mobile sector of the belt is mainly formed by the Molise-Sannio (MS) wedge. The internal extensional border of that wedge, mainly corresponding to the Irpinia and Benevento zones, is marked by a series of seismotectonic troughs and normal faults (e.g., Ascione et al. 2003, 2007 and references therein). The zone where the MS wedge interacts with the Latium-Abruzzi (LA) platform, a site of strong earthquakes, is characterized by transpressional features mainly recognized east and south of the Maiella structural high (e.g., Calamita et al. 2006; Esestime et al. 2006; Pizzi et al. 2007).

In the Central Apennines, mainly formed by the LA carbonate platform, there are two main SE-NW parallel decoupling zones, both related to sinistral transtensional fault systems, as suggested by neotectonic deformation and earthquake focal mechanisms (e.g., Cello et al. 1997, 1998; Amoruso et al. 1998; Tondi 2000; Piccardi et al. 1999, 2006; Galadini and Messina 2001). These fault systems, both characterized by very strong seismicity, are associated with the Aquila and the Fucino basins (Fig. 2).

In the Northern Apennines, the mobile sector of the belt is mainly formed by the RomagnaMarche-Umbria (RMU) and Ligurian wedges. Under the push of the eastern part of the LatiumAbruzzi platform (ELA), this arc tends to extrude outward, causing thrusting and extension at its external and internal boundaries, respectively, both associated with significant seismic activity (e.g., Boncio and Lavecchia 2000; Martini et al. 2001; Viti et al. 2006; Basili and Barba 2007; Cenni et al. 2008).

It is worth noting that the locations of the Roman and Neapolitan volcanic provinces (Marra 2001; Milia and Torrente 2003) fairly well correspond to the internal boundaries of the RMU and MS wedges, respectively (Fig. 2), which is 


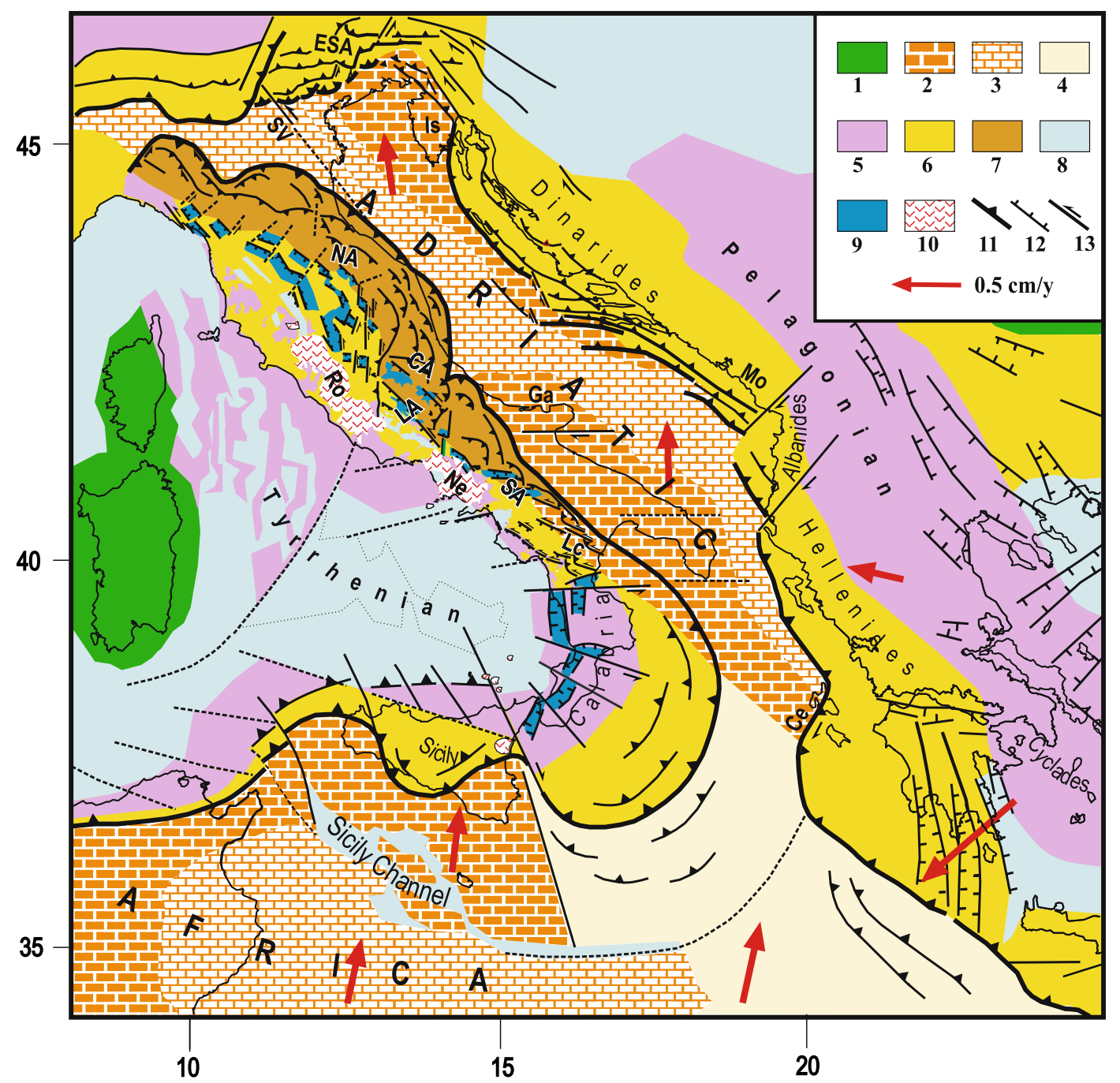

Fig. 1 Tentative reconstruction of the post-Middle Pleistocene kinematic and tectonic patterns in the Central Mediterranean region. 1 European continental domain; 2, 3 Africa-Adriatic continental and thinned continental domains; 4 Ionian Tethys oceanic domain; 5 remnants of the Alpine belt; 6 Peri-Adriatic belts; 7 External part of the Apennines belt moving in connection with the Adriatic plate; 8,9 Non-active and active extensional basins; 10 Quaternary magmatism; 11, 12, 13 major compressional, extensional and transcurrent tectonic features. The divergence between the external (mobile) and internal (fixed) sectors of the Apennines is accommodated by tensional to transtensional deformation in the axial part of the belt, associated with a series of seismic troughs and normal faults. Red arrows indicate motions with respect to Eurasia. Thin lines identify present geographical contours. $C A$ Central Apennines; $C e$ Cephalonia fault system; $G a$ Gargano zone; Is Istria; $L A$ Latium-Abruzzi platform; $L c$ Lucanian Apennines; Mo Montenegro zone; NA Northern Apennines; Ro, Ne Roman and Neapolitan volcanic provinces; $S A$ Southern Apennines; $E S A$ eastern Southern Alps; $S V$ Schio-Vicenza fault system consistent with the hypothesis that the generation of these provinces was closely connected with the strong extensional regime that developed in the wake of these extruding wedges since the late
Pliocene (e.g., Tamburelli et al. 2000; Viti et al. 2006).

The sector of the mobile Apennines belt that first adjusts to the periodic accelerations of the 


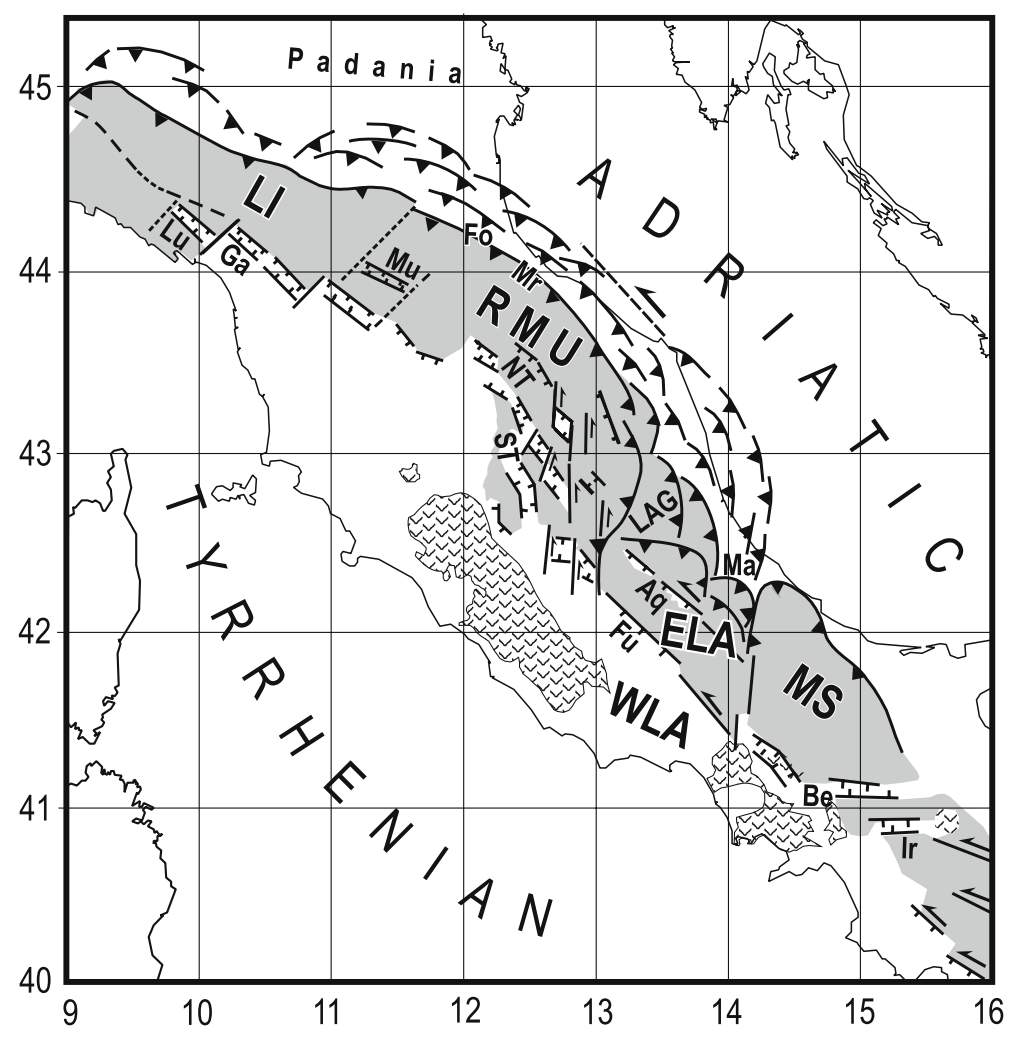

Fig. 2 More detailed tectonic sketch of the Apennine belt, evidencing the major orogenic wedges (shaded) carried by the Adriatic plate and the main tectonic features, which are presumed to decouple the above wedges from the adjacent structures. $A q$ Aquila transtensional fault system, $B e$ Benevento zone, ELA Eastern sector of the Latium-Abruzzi platform, Fo Forlivese zone, Fu Fucino transtensional fault system, $G a$ Garfagnana trough, $M a$ Maiella structural high, Ir Irpinia zone, $L A G$ Laga units, $L I$ Ligurian units, $L u$ Lunigiana trough, $M S$ Molise-Sannio units, $M u$ Mugello trough, NT Northern Tiber trough, $R M U$ Romagna-Marche-Umbria units, ST Southern Tiber trough, $M r$ Marecchia thrust, WLA Western sector of the Latium-Abruzzi platform. Symbols as in Fig. 1
Adriatic plate (triggered by major earthquakes at the main peri-Adriatic decoupling zones) is the MS wedge, which in turn stresses ELA and consequently the RMU wedge in the Northern Apennines.

The system of NW-SE sinistral strike-slip faults, locally associated with pull-apart extensional troughs, which is recognized in the Lucanian Apennines (e.g., Cello and Mazzoli 1999; Cello et al. 2003; Catalano et al. 2004; Maschio et al. 2005) accommodates the relative motion between the Adriatic-Molise-Sannio system and the outward escaping Calabrian wedge (Viti et al. 2006).

The motion of the Adriatic plate at its northern boundary (Fig. 1) is mainly accommodated by transpressional seismotectonic activity along the border of the Southern Alps (e.g., Benedetti et al. 2000; Galadini et al. 2005). In the northernmost Dinarides, the relative motion between the Adriatic plate and the Carpatho-Pannonian zone is accommodated by a system of dextral faults (e.g., Poljak et al. 2000).

South of the Istria peninsula, compressional and transpressional features are recognized along the eastern border of the Adriatic plate (Fig. 1). This deformation, associated with high seismotectonic activity, accommodates the oblique underthrusting of the Adriatic plate beneath the Southern Dinarides (e.g., Markušić and Herak 1999). Compressional deformation in the Northern Hellenides and transpressional deformation 
at the Cephalonia fault system (e.g., Louvari et al. 1999, 2001) accommodates the convergence between the Aegean wedge and the Southern Adriatic plate (e.g., Mantovani et al. 2006). The decoupling of the Adriatic-Dinarides system from the Aegean-Hellenides one is also accommodated by a complex pattern of NW-SE thrusts and NESW dextral shear zones in the Albanides (e.g., Aliaj 2006; Bennett et al. 2008).

Considering the kinematic/tectonic synthesis described above (Fig. 1) and the concept of accelerated plate tectonics (e.g., Anderson 1975), one may expect some interaction among periAdriatic seismic sources. For instance, seismicity in the Apennines belt may be favored by decoupling earthquakes at the Dinarides-AlbanidesHellenides transpressional zones, since such events allow acceleration of the Adriatic plate, which is closely connected with the MS wedge, as discussed earlier. Further effects of the Adriatic plate acceleration may be expected in the Central and Northern Apennines, as the ELA, RMU, and Ligurian wedges accelerate, under the push of the MS wedge. Most probably, the strongest resistance to the acceleration of the external part of the belt is encountered in the Central Apennines, which, being mainly formed by a thick carbonate platform, are characterized by a higher strength with respect to the Southern and Northern Apennines. Thus, major decoupling earthquakes in the axial part of the LA platform, at the Aquila or Fucino shear zones, may influence seismicity in the Northern Apennines. The next section describes some regular occurrence of major earthquakes in the Apennines belt, which might be explained in the framework of the proposed tectonic setting.

\section{Long-term earthquake forecasting in the Southern Apennines}

The possible influence that the major decoupling earthquakes at the eastern Adriatic collisional boundary (Dinarides and Hellenides) may have on the seismicity of Apennines has been explored by Mantovani and Albarello (1997). Such kind of a study, carried out with updated seismic catalogues and taking into account the information more recently acquired on the tectonic setting, suggests that the sectors of the western and eastern Adriatic borders that present the best time correlation between major earthquakes are the ones shown in Fig. 3. The list of major events that have occurred since 1200 in those zones (Table 1 ) shows that in the most recent period (since 1850), presumably characterized by the most complete seismic catalogue, the major Southern Apennines events $(\mathrm{M}>5.5)$ have been almost regularly preceded, within less than 4 years, by strong earthquakes $(M>6)$ in the Southern DinaridesAlbanides zone.

Numerical simulation of post-seismic relaxation induced by the last strong event in the

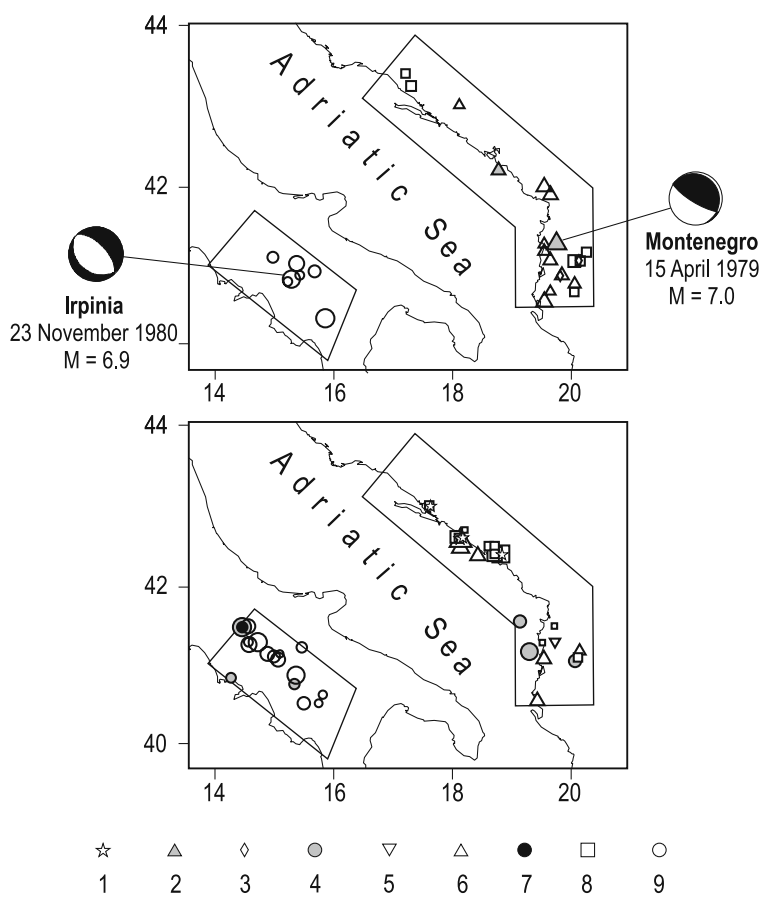

Fig. 3 Geometries (boxes) of the presumably interrelated Southern Apennines and Southern Dinarides-Albanides zones, sites of the earthquakes given in Table 1. The upper and lower pictures respectively show the distributions of the events following and preceding 1850 . Symbols refer to the following papers: 1 Albini (2004); 2 Ambraseys (1990); 3 Comninakis and Papazachos (1986); 4 Guidoboni and Comastri (2005); 5 Papazachos and Comninakis (1982); 6 Papazachos and Papazachos (1989); 7 Postpischl (1985); 8 Shebalin et al. (1974); 9 Working Group CPTI (2004). The focal mechanisms of the last two presumably correlated events in the two zones (Boore et al. 1981; Giardini 1993) are given close to the respective boxes in the upper frame 
Table 1 List of major earthquakes that occurred since 1200 in the Southern Apennines $(M>5.5)$ and Southern Dinarides-Albanides $(M \geqslant 6)$ zones shown in Fig. 3

\begin{tabular}{ll}
\hline Southern Apennines & Southern Dinarides \\
\hline $1980(6.9)$ & $1979(7.0,6.3)$ \\
$1962(6.2)$ & $1962(6.0), 1959(6.0,6.4)$ \\
& $1942(6.0)$ \\
$1930(6.7)$ & $1927(6.0), 1926(6.1)$ \\
& $1923(6.2)$ \\
$1910(5.9)$ & $1907(6.2), 1906(6.5), 1905(6.6)$ \\
& $1870(6.4), 1869(6.2), 1865(6.2)$ \\
$1857(7.0)$ & $1855(6.5)$ \\
$1851(6.3), 1853(5.9)$ & $1851(6.1,6.7,6.0,6.1)$ \\
& $1843(\mathrm{VIII})$ \\
$1836(I X)$ & $1833(X)$ \\
$1831(V I I I)$ & $1827(\mathrm{VIII})$ \\
$1826(I X)$ & $1823(I X)$ \\
& $1816(\mathrm{VIII})$
\end{tabular}

$1805(\mathrm{X})$

$1732(\mathrm{X})$

$1702(\mathrm{X})$

$1694(\mathrm{XI})$

$1688(\mathrm{XI})$

$1517($ VIII)

1466 (VIII)

$1456(I X, X I, X I, I X)$

$1386($ VIII)

$1361(X)$

1293 (IX)

$1273(I X)$

Before 1850 , macroseismic intensities are indicated by Roman numerals. The presumably correlated events are italicized. Data taken from Shebalin et al. (1974), Makropoulos and Burton (1981), Papazachos and Comninakis (1982), Postpischl (1985), Comninakis and Papazachos (1986), Anderson and Jackson (1987), Jackson and McKenzie (1988), Papazachos and Papazachos (1989), Ambraseys (1990), Albini (2004), Working Group CPTI (2004), Guidoboni and Comastri (2005)
Southern Dinarides (Montenegro 1979, M = 7.0) provides a plausible physical explanation for the observed delays between Dinaric and Southern Apennines events (Viti et al. 2003). This explanation is based on the frictional behavior of seismic faults (e.g., Niemeijer and Spiers 2007; Savage and Marone 2007) and on the hypothesis that the arrival of the strain-rate peak induced by the triggering earthquake determines the highest probability of induced seismic events (e.g., Pollitz et al. 1998; Viti et al. 2003; Cenni et al. 2008). Considering that the Southern Apennines is the seismotectonic zone nearest to the triggering Dinaric sources and that strain perturbation induced by post-seismic relaxation experiences a fast attenuation with distance, it seems reasonable to expect that the most evident effects of such phenomenon occur in that zone.

To assess the statistical significance of the observed correlation for the period following 1850 (Table 1), we have evaluated by the Monte Carlo procedure the probability that all the seven Apenninic events have occurred by chance within a delay comprised between 3 and 5 years from a Dinaric earthquake. Accordingly, 10,000 sets of seven random Apenninic events have been generated with uniform probability (Press et al. 1992) for the time interval 1850-2007, and the number of successful correspondences has been computed for each set. The results of this test (Table 2) indicate that the observed full correspondence has a probability ranging between $0.04 \%$ and $0.4 \%$. Similar values can be obtained by simply assuming that the probability of an Apenninic event being predicted by chance is given by the ratio between the total prediction time and the entire time interval considered. This probability and the binomial distribution can be used to compute the probability that seven times out of seven trials, an Apenninic event occurs by chance in the time interval covered by the Dinaric predictions. The result of this computation $(0.02-0.1 \%)$ fairly agrees with the one obtained by the Monte Carlo procedure. The fact that the above probability is largely lower than the conventional threshold value of $5 \%$ underlines the statistical significance of the observed correlation.

In order to better understand the practical usefulness of the observed correlation, we have also 
Table 2 Results of statistical tests applied to post 1850 earthquakes in Table 1

\begin{tabular}{|c|c|c|c|c|c|c|c|c|c|c|c|c|}
\hline $\begin{array}{l}\mathrm{PT} \\
\text { (year) }\end{array}$ & $\mathrm{Nsu}$ & Nna & $\mathrm{Nfa}$ & $\begin{array}{l}\text { Nsu + Nna } \\
+\mathrm{Nfa}\end{array}$ & FT & YP (year) & Sig (MC) & Sig (Bin) & Psu & Pfa & Pna & $\mathrm{Ppr}$ \\
\hline 3 & 8 & 0 & 8 & 16 & 0.29 & 46 & 0.0004 & 0.0002 & 0.50 & 0.50 & 0.10 & 0.90 \\
\hline 4 & 9 & 0 & 8 & 17 & 0.33 & 53 & 0.0018 & 0.0004 & 0.56 & 0.44 & 0.09 & 0.91 \\
\hline 5 & 11 & 0 & 5 & 16 & 0.38 & 60 & 0.0041 & 0.0011 & 0.67 & 0.33 & 0.08 & 0.92 \\
\hline
\end{tabular}

The considered time interval is 158 years (1850-2007)

$P T$ precursory time (the Apennine earthquake is assumed to occur within PT years after the Dinaric event); Nsu number of successful predictions; Nna number of non alarms; Nfa number of false alarms; FT fraction of time covered by alarm; YP number of years covered by alarm; Sig (MC) and Sig (Bin) significance level (probability to have by chance the observed number of successful predictions) computed by the Monte Carlo and Binomial approaches respectively; Psu probability of a successful prediction; Pfa probability of a false alarm; Pna probability of a failed alarm; Ppr probability that an Apenninic event is predicted

evaluated, given an event in the Dinarides, the probability of a successful prediction (Psu), a false alarm (Pfa), a failed alarm (Pna), and a predicted event (Ppr). To this purpose, we have adopted a Bayesian approach (Rhoades and Evison 1979), which provides that the above probabilities can be computed on the basis of the number of successful predictions (Nsu), false alarms (Nfa), and failed alarms (Nna) by the following relations:

$\mathrm{Psu}=(\mathrm{Nsu}+1) /(\mathrm{Nsu}+\mathrm{Nfa}+2)$

$\mathrm{Pfa}=1-\mathrm{Psu}$

Pna $=(\mathrm{Nna}+1) /(\mathrm{Nna}+\mathrm{Nsu}+2)$

Ppr $=1-$ Pna

The most significant information obtained by this investigation (Table 2) is the low value of the probability (Pna) that a major earthquake occurs in the Southern Apennines without the occurrence of a Dinaric precursor in the previous few years. From the physical point of view, this result would imply that seismic slip at one of the Southern Apennines faults can hardly occur without the decisive contribution of the sudden strain rate increase (even reaching ten times the normal value) induced by post-seismic relaxation (Viti et al. 2003). However, the limited length of the period considered in the above tests does not allow us to know the real uncertainty that may be associated with the above probabilities.
Although the completeness of seismic catalogues in the period preceding 1850 cannot easily be checked, the available information on the major earthquakes that occurred in both the involved zones from 1200 to 1849 (Table 1) might provide further support to the more recent correlation. For instance, it is noteworthy that in the period preceding 1600, several strong Southern Apennines earthquakes have occurred a few years after major events in the Dinaric zone. The worst correspondence between Apenninic and Dinaric events occurs from about 1600 to 1850 . In this regard, one could note that in the 1668-1832 time interval, known seismic activity in the Southern Dinarides-Albanides zone is very scarce, with only one moderate event $(1780, \mathrm{M}=6)$. The fact that this anomalously low activity mainly coincides with the period of maximum influence of the Ottoman domination, which did not favor the documentation of seismic damages in the affected zones (e.g., Albini 2004; Guidoboni and Comastri 2005), might not be a mere coincidence. One could also note that the most intense seismic activations of major faults in the Gargano zone (1627, $\mathrm{M}=6.7$ and $1646, \mathrm{M}=6.3$ ) occurred during the longest time interval not characterized by major earthquakes in the Southern Apennines (15611688). Since the dextral strike-slip mechanism of a Gargano earthquake (e.g., Piccardi et al. 2006 and references therein) is expected to induce in the Southern Apennines a strain perturbation opposite to that induced by Dinaric events (roughly NE-SW extension, e.g., Viti et al. 2003), it may be that the above Gargano earthquakes contributed 
to reducing strain accumulation in the Southern Apennines normal faults and, consequently, delayed the next earthquakes in that zone.

The results given in Table 2 indicate that the most reliable Dinaric precursors $(\mathrm{Psu}=67 \%$ ) use a forecasting time interval of 5 years. Considering that the magnitude of the strain perturbation induced by strong Dinaric events is significantly higher than the sensitivity of geodetic observations (Viti et al. 2003), the occurrence of a Dinaric event should stimulate the organization of suitable geodetic surveys or other geophysical observations in the zones involved in order to gain further insights into the mechanism of longrange interaction between seismic sources in the peri-Adriatic zones. Such information could allow a reduction of false alarms, improving the practical usefulness of the observed interrelation for long-term earthquake prediction in the Southern Apennines.

\section{Long-term earthquake forecasting in the Northern Apennines}

The proposed kinematic/tectonic synthesis (Figs. 1 and 2) suggests that the deformation and associated seismic activity in the Northern Apennines is mainly driven by the indentation of the eastern part of the LA platform. A detailed description of the evidence and arguments that support this interpretation is given by Viti et al. (2004, 2006) and Cenni et al. (2008). When a strong decoupling earthquake occurs along one of the two main shear zones longitudinally cutting the LA platform, the corresponding decoupled ELA block accelerates, causing an increase of stress and possibly of seismotectonic activity in the Northern Apennines. Depending on which of the two decoupling LA shear zones is activated, the above indentation mechanism may produce different deformation patterns and related seismicity distribution in the Northern Apennines. If seismic slip occurs at the more external Aquila fault system, the decoupled ELA wedge, being relatively narrow, mainly stresses the Laga wedge and the outermost sector of RMU.

Three possible examples of this case, characterized by very strong earthquakes, are shown in
Fig. 4. The first picture (Fig. 4a) shows the seismic sequence that presumably started in 1349 with two strong earthquakes in the Central Apennines, one at the northern border of the MS wedge $(\mathrm{M}=6.6)$ and another at the Aquila shear zone $(M=6.5)$. These decoupling earthquakes were followed by seismic activity along the inner border of RMU. Figure $4 \mathrm{~b}$ shows the seismic sequence that started in 1456 in the Southern Apennines. Initially, three almost simultaneous strong earthquakes (1456, $\mathrm{M}=7,6.6$, and 6.3) struck the internal extensional border of MS and one event (1456, M = 5.8) activated the Aquila shear decoupling zone. The presumed consequent acceleration of MS and ELA, favored by the above decoupling events, increased stresses in RMU, causing seismic activity along the internal border of that wedge. The activation of the Aquila fault system continued with the occurrence of another major event (1461, $M=6.5)$. As in the previous cases, the decoupling earthquakes in LA were followed by moderate earthquakes at the extensional border of RMU. Figure $4 \mathrm{c}$ shows the earthquake sequence that started in the Southern Apennines in the 1688 and then migrated northward along the axial zone of the belt, reaching the southernmost edge of RMU. In the first part of this sequence, three strong earthquakes occurred along the internal extensional border of MS (Irpinia-Benevento zone: 1688, $\mathrm{M}=6.7 ; 1694, \mathrm{M}=6.9$; and 1702, $\mathrm{M}=6.3$ ). The consequent decoupling might have allowed MS to accelerate, with the consequent increase of shear stress in the axial part of LA. This hypothesis might explain why, in 1703, a very strong earthquake took place at the Aquila decoupling fault system, which ruptured up to the Southern Tiber valley zone (Cello et al. 1998), and why, in 1706, a major event (Maiella, $M=6.6$ ) occurred at the transpressional border between MS and ELA.

When, instead, strong seismic slip occurs at the Fucino decoupling fault system, as occurred in 1915 with the Avezzano earthquake ( $\mathrm{M}=$ 7.0), a wider sector of ELA decouples from WLA and accelerates, significantly stressing the Northern Apennines (Fig. 2). In this circumstance, one may expect that the whole RMU wedge, not only its easternmost sector, is stressed by ELA, implying a lower transtensional stress within RMU and higher stress at the northern part 

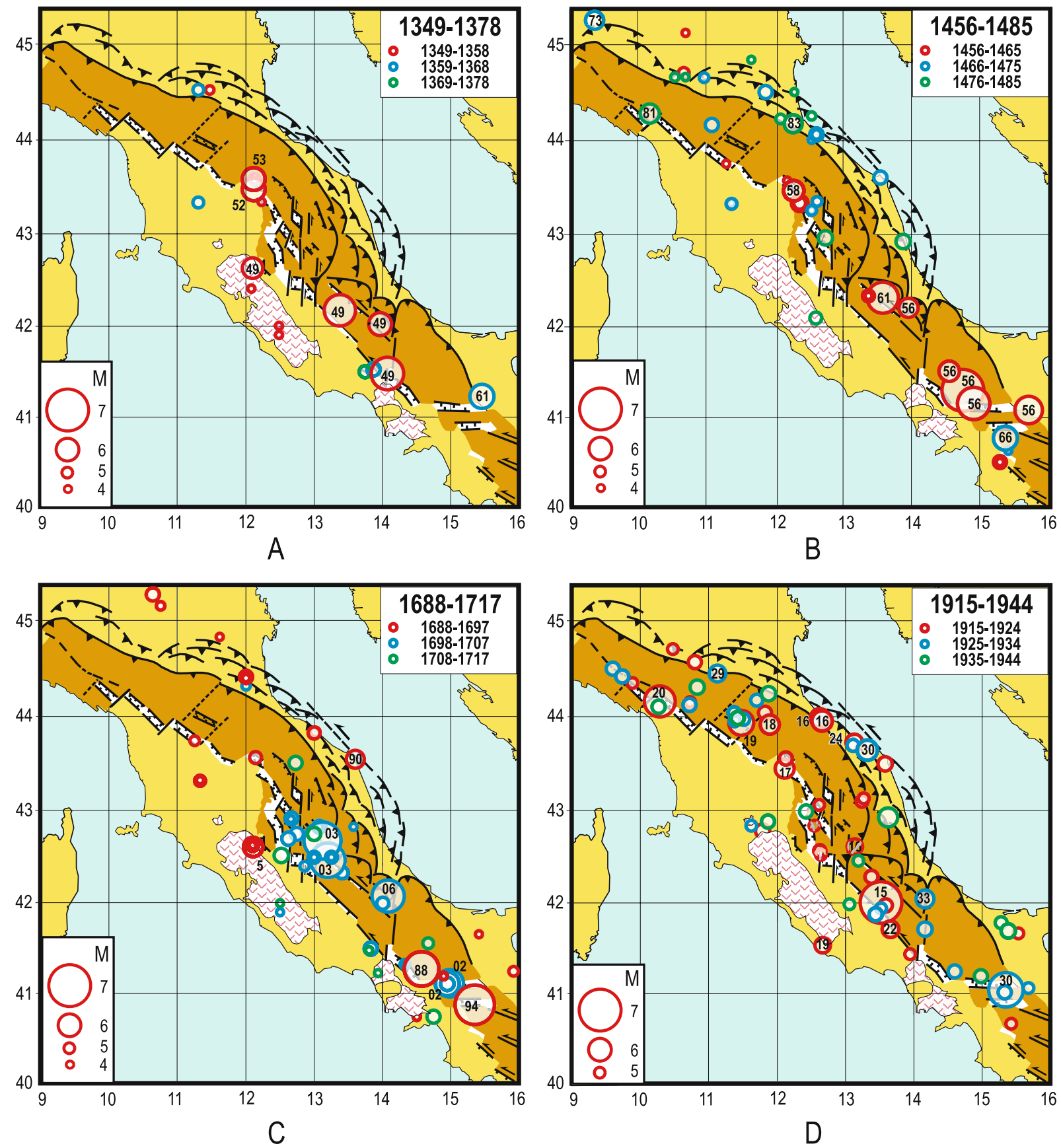

Fig. 4 Distribution of major earthquakes in the mobile sector of the Apennines belt during four most intense seismic crises. See text for comments. Numbers inside or close to largest circles $(\mathrm{M}>5.5)$ indicate the year of oc-

currence. Data taken from Working Group CPTI (2004) and Guidoboni and Comastri (2005). Tectonic scheme and symbols as in Fig. 2

of this block, where it collides with the PadanianAdriatic structures and tends to decouple from the Ligurian wedge (Fig. 2). This interpretation

is consistent with the fact that the activations of the Aquila fault system were followed by seismic activity at the internal boundary of RMU 
(Fig. 4a-c), whereas the seismic activity that followed the activation of the Fucino system mainly affected the northern edge of RMU and the internal border of the Ligurian wedge (Fig. 4d). In particular, one could note that the first major seismic effect of the Avezzano earthquake took place at the outer compressional border of RMU (Marecchia, 1916, $\mathrm{M}=5.8$ and 5.9). The subsequent event occurred in the internal extensional border of that wedge (Northern Tiber trough, 1917, $\mathrm{M}=5.7)$. The Forlivese zone, where the third major earthquake took place (1918, $\mathrm{M}=$ 5.7), probably corresponds to the transpressional decoupling belt between the RMU and Ligurian units (Costa 2003; Viti et al. 2004). The last two major events of the 1916-1920 sequence took place along the internal extensional border of the Ligurian wedge (Mugello, 1919, $\mathrm{M}=6.2$ and Garfagnana, 1920, $M=6.5$ ), suggesting that the above phase also involved an outward displacement of that wedge.

Numerical modeling of post-seismic relaxation induced by the 1915 Avezzano earthquake (Cenni et al. 2008) shows that the delays of the major Northern Apennines earthquakes (1916, 1917, 1918, 1919, and 1920) with respect to the 1915 triggering event are compatible with the travel times of the induced strain-rate peaks.

\section{Conclusions}

It is argued that the probability of major earthquakes in the Southern and Northern Apennines significantly increases in the first few years following strong decoupling earthquakes in the Southern Dinarides-Albanides and Central Apennines zones, respectively. This hypothesis is based on the influence that the geodynamic and tectonic settings of the Central Mediterranean region may have on the time-space distribution of major earthquakes, considering the expected effects of post-seismic relaxation. The reliability of the proposed interpretation is supported by the recognition of regular occurrence of major earthquakes in the Apennines region, in particular by the fact that since 1850 all major earthquakes $(M>5.5)$ in the Southern Apennines have been preceded within few years by strong seismic events $(M \geqslant 6)$ in the
Southern Dinarides-Albanides zone. Numerous examples of correlated major events exist in the previous history (1200-1850) of these two zones, even though the number of non-correlated events is higher than in the recent period.

The observed seismic interrelation and the underlying tectonic interpretation may contribute to defining the time-dependent seismic hazard in the Southern Apennines.

For instance, the statistical analysis of the post1850 data set suggests, with a low level of uncertainty, that the probability of a major earthquake in the Southern Apennines is low (about 10\%) when no major events have occurred in the related Dinaric zone in the previous few years. A higher level of uncertainty is associated with the other aspect of that problem, that is, the probability that a major Dinaric event is a successful precursor of an Apennine earthquake. In particular, the probability of false alarms is relevant (50\% within 3 years, $33 \%$ within 5 years). This last problem could be attenuated by a deeper understanding of the mechanism which underlies long-range interaction of seismic sources. Such improvement might be achieved by more realistic quantifications of post-seismic relaxation induced by peri-Adriatic strong earthquakes, taking into account more detailed structural contexts and possibly more realistic modeling of seismic sources. Such a study should be conducted for a number of past strong earthquakes, looking for a satisfactory explanation of post-seismic earthquake distribution in the surrounding zones. Other precious opportunities to gain insights into this problem will be offered by the occurrence of future major earthquakes in the presumably interrelated zones, emphasized by the considerably improved observation potentiality provided by continuous geodetic monitoring with increasingly dense global positioning networks.

The hypothesis that long-range interaction of seismic sources also occurs in the Central and Northern Apennines is only tentative for the moment, since it is not supported by a significant seismic correlation like the one recognized in the Southern Apennines. However, notwithstanding the lack of such an empirical validation, we think that the existence of the above phenomenon is plausibly suggested by important evidence and 
arguments, as indicated in the text. Thus, the occurrence of future strong decoupling earthquakes in the Central Apennines should be used to set up suitable geodetic and geophysical surveys, aimed at reconstructing the time-space evolution of the migrating strain perturbation.

The geodetic observations carried out in the Apennines belt during the last 5-10 years have allowed a fairly accurate definition of the velocity field in the study area, presumably representative of a nonperturbed situation. Such information may then be used as a reference frame for recognizing possible future anomalous patterns of the velocity and strain fields.

Acknowledgements We are grateful to Prof. R. Scarpa, an anonymous Referee and the Editors of this Special Volume, whose comments have significantly improved the work. This research has been funded by the Italian Ministero della Ricerca (PRIN) and Presidenza del Consiglio del Ministri-Dipartimento della Protezione Civile (DPC) Project S2 "Assessing the Seismogenic potential and the probability of strong earthquakes in Italy" (Slejko and Valensise coord.).

\section{References}

Albini P (2004) A survey of past earthquakes in the Eastern Adriatic (14th to early 19th century). Ann Geophys 47:675-703

Aliaj Sh (2006) The Albanian orogen: convergence zone between Eurasia and the Adria microplate. In: Pinter $\mathrm{N}$ et al (eds) The Adria microplate: GPS geodesy tectonics and hazards. Springer, Berlin, pp 133-149

Ambraseys NN (1990) Uniform magnitude re-valuation of European earthquakes associated with strong-motion records. Earth Eng Struct Dyn 19:1-20. doi:10.1002/ eqe. 4290190103

Amoruso A, Crescentini L, Scarpa R (1998) Inversion of source parameters from near- and far-field observations: an application to the 1915 Fucino earthquake, central Apennines, Italy. J Geophys Res 103:29989_ 29999. doi:10.1029/98JB02849

Anderson DL (1975) Accelerated plate tectonics. Science 167:1077-1079. doi:10.1126/science.187.4181.1077

Anderson H, Jackson J (1987) Active tectonics of the Adriatic region. Geophys J R Astron Soc 91:937-983

Ascione A, Caiazzo C, Cinque A (2007) Recent faulting in Southern Apennines (Italy): geomorphic evidence, spatial distribution and implications for rates of activity. Boll Soc Geol It 126:293-305

Ascione A, Cinque A, Improta L, Villani F (2003) Late Quaternary faulting within the Southern Apennines seismic belt: new data from Mt. Marzano area
(Southern Italy). Quaternary Int 101-102:27-41. doi:10.1016/S1040-6182(02)00127-1

Basili R, Barba S (2007) Migration and shortening rates in the northern Apennines, Italy: implications for seismic hazard. Terra Nova 19:462-468. doi:10.1111/j.13653121.2007.00772.x

Benedetti L, Tapponnier P, King GCP, Meyer B, Manighetti I (2000) Growth folding and active thrusting in the Montello region, Veneto, northern Italy. J Geophys Res 105:739-766. doi:10.1029/1999JB 900222

Bennett RA, Hreinsdottir S, Buble G, Bašić T, Bašić Ž, Marjanovic M, Casale G, Gendaszek A, Cowan D (2008) Eocene to present subduction of southern Adria mantle lithosphere beneath the Dinarides. Geology 36:3-6. doi:10.1130/G24136A.1

Boncio P, Lavecchia G (2000) A structural model for active extension in Central Italy. J Geodynamics 29:233-244. doi:10.1016/S0264-3707(99)00050-2

Boore DM, Sims JD, Kanamori H, Harding S (1981) The Montenegro, Yugoslavia, earthquake of April, 15, 1979: source orientation and strength. Phys Earth Planet Inter 27:133-142. doi:10.1016/0031-9201(81) 90041-8

Calamita F, Paltrinieri W, Esestime P, Viandante MG (2006) Assetto strutturale crostale dell'appennino centro-meridionale. Rend Soc Geol It Nuova Serie 2:103-107

Catalano S, Monaco C, Tortorici L (2004) NeogeneQuaternary tectonic evolution of the southern Apennines. Tectonics 23:TC2003. doi:10.1029/2003 TC001512

Cello G, Mazzoli S (1999) Apennine tectonics in southern Italy: a review. Geodynamics 27:191-211. doi:10.1016/ S0264-3707(97)00072-0

Cello G, Mazzoli S, Tondi E, Turco E (1997) Active tectonics in the central Apennines and possible implications for seismic hazard analysis in peninsular Italy. Tectonophysics 272:43-68. doi:10.1016/S00401951(96)00275-2

Cello G, Mazzoli S, Tondi E (1998) The crustal fault structure responsible for the 1703 earthquake sequenze of central Italy. J Geodynamics 26:443-460. doi:10.1016/ S0264-3707(97)00051-3

Cello G, Tondi E, Micarelli L, Mattioni L (2003) Active tectonics and earthquake sources in the epicentral area of the 1857 Basilicata earthquake (southern Italy). J Geodyn 36:37-50. doi:10.1016/S0264-3707 (03)00037-1

Cenni N, Viti M, Baldi P, Mantovani E, Ferrini M, D'Intinosante V, Babbucci D, Albarello D (2008) Short-term (geodetic) and long-term (geological) velocity fields in the Northern Apennines. Boll Soc Geol Ital 127(1):93-104

Comninakis PE, Papazachos BC (1986) Catalogue of earthquakes in Greece and surrounding area for the period 1901-1985. University of Thessaloniki, Geophys Lab Pub1

Costa M (2003) The buried, Apenninic arcs of the Po Plain and northern Adriatic Sea (Italy): a new model. Boll Soc Geol It 122:3-23 
Esestime P, D'Arcangelo S, Paltrinieri W, Calamita F (2006) Strutture traspressive della Catena Apula Sepolta (Appennino Meridionale, settore campanomolisano). Rend Soc Geol Ital 2:135-137

Galadini F, Messina P (2001) Plio-Quaternary changes of the normal fault architecture in the central Apennines (Italy). Geodin Acta 14:321-344. doi:10.1016/S09853111(01)01076-2

Galadini F, Poli ME, Zanferrari A (2005) Seismogenic sources potentially responsible for earthquakes with $M \geq 6$ in the eastern southern Alps (ThieneUdine sector, NE Italy). Geophys J Int 161:739-762. doi:10.1111/j.1365-246X.2005.02571.x

Giardini D (1993) Teleseismic observation of the November 23 1980, Irpinia earthquake. Ann Geofis 36:17-25

Guidoboni E, Comastri A (2005) Catalogue of earthquakes and tsunamis in the Mediterranean area from the 11th to the 15th century. Istituto Nazionale di Geofisica e Vulcanologia Roma, pp 1037

Jackson J, McKenzie D (1988) The relationship between plate motions and seismic moment tensors and the rates of active deformation in the Mediterranean and Middle East. Geophys J 93:45-73. doi:10.1111/ j.1365-246X.1988.tb01387.x

Louvari E, Kiratzi AA, Papazachos BC (1999) The Cephalonia Transform Fault and its extension to western Lefkada Island (Greece). Tectonophysics 308: 223-236. doi:10.1016/S0040-1951(99)00078-5

Louvari E, Kiratzi AA, Papazachos BC, Katzidimitriou P (2001) Fault-plane solutions determined by waveform modelling confirm tectonic collision in the eastern Adriatic. Pure Appl Geophys 158:1613-1637. doi:10. 1007/PL00001236

Makropoulos KC, Burton PW (1981) A catalogue of seismicity in Greece and adjacent areas. Geophys J R Astron Soc 65:741-762

Mantovani E (2005) Evolutionary reconstruction of the Mediterranean region: extrusion tectonics driven by plate convergence. In: Finetti IR (ed) Deep seismic exploration of the Central Mediterranean and Italy CROP PROJECT, vol 32. Elsevier, pp 705-746

Mantovani E, Albarello D (1997) Medium-term precursors of strong earthquakes in southern Italy. Phys Earth Planet Inter 101:49-60. doi:10.1016/S00319201(96)03241-4

Mantovani E, Albarello D, Babbucci D, Tamburelli C (1997) Recent/present tectonic processes in the Italian region and their relation with seismic and volcanic activity. Ann Tectonicae 11:27-57

Mantovani E, Viti M, Babbucci D, Tamburelli C, Albarello D (2006) Geodynamic connection between the indentation of Arabia and the Neogene tectonics of the central-eastern Mediterranean region. In: Dilek Y, Pavlides S (eds) Post-collisional tectonics and magmatism in the Mediterranean Region and Asia. Geol Soc Am, special vol. 490, pp 15-49

Mantovani E, Viti M, Babbucci D, Tamburelli C (2007a) Major evidence on the driving mechanism of the
Tyrrhenian-Apennines trench-arc-back arc system from CROP seismic data. Boll Soc Geol Ital 126: 459-471

Mantovani E, Viti M, Babbucci D, Albarello D (2007b) Nubia-Eurasia kinematics: an alternative interpretation from Mediterranean and North Atlantic evidence. Ann Geophys 50:311-336

Markušić S, Herak M (1999) Seismic zoning of Croatia. Nat Hazards 18:269-285

Marra F (2001) Strike-slip faulting and block rotation: a possible triggering mechanism for lava flows in the Alban Hills? J Struct Geol 23:127-141. doi:10.1016/ S0191-8141(00)00068-7

Marsan D, Bean CJ (2003) Seismicity response to stress perturbations, analysed for a world-wide catalogue. Geophys J Int 154:179-195. doi:10.1046/j.1365246X.2003.01963.x

Marsan D, Bean CJ, Steacy S, McCloskey J (2000) Observation of diffusion processes in earthquake populations and implications for the predictability of seismicity systems. J Geophys Res 105:81-94. doi:10.1029/ 2000JB900232

Martini IP, Sagri M, Colella A (2001) Neogene-Quaternary basins of the inner Apennines and Calabrian arc. In: Vai GB, Martini IP (eds) Anatomy of an Orogen: the Apennines and Adjacent Mediterranean Basins. Kluwer, London, pp 375-400

Maschio L, Ferranti L, Burrato P (2005) Active extension in Val d'Agri area, southern Apennines, Italy: implications for the geometry of the seismogenic belt. Geophys J Int 162:591-609. doi:10.1111/j.1365246X.2005.02597.x

Milia A, Torrente MM (2003) Late-Quaternary volcanism and transtensional tectonics in the Bay of Naples, Campanian continental margin, Italy. Mineral Petrol 79:49-65. doi:10.1007/s00710-003-0001-9

Mulargia F, Geller RJ (2003) Earthquake science and seismic risk reduction, vol 32. NATO Science Series. Kluwer Academic Publ. pp 338

Niemeijer AR, Spiers CJ (2007) A microphysical model for strong velocity weakening in phyllosilicate-bearing fault gouges. J Geophys Res 112:B10405. doi:10.1029/ 2007JB005008

Papazachos BC, Comninakis PE (1982) A catalogue of historical earthquakes in Greece in and surrounding area, vol 5. Publ Geophys Lab, Univ Thessaloniki, pp 24

Papazachos BC, Papazachos CB (1989) The earthquakes of Greece. Publ Geophys Lab, University of Thessaloniki, pp 356

Piccardi L, Gaudemer Y, Tapponnier P, Boccaletti M (1999) Active oblique extension in the central Apennines (Italy): evidence from the Fucino region. Geophys J Int 139:499-530. doi:10.1046/j.1365-246x. 1999.00955.x

Piccardi L, Tondi G, Cello G (2006) Geo-structural evidence for active oblique extension in South-Central Italy. In: Pinter $\mathrm{N}$ et al (eds) The Adria microplate: GPS geodesy, tectonics and hazard. Springer, Berlin, pp 95-108 
Pizzi A, Pomposo G, Scisciani V, Galadini F (2007) Evidenze geologiche e morfologiche di strutture in crescita nell'area periadriatica abruzzese colpita dal terremoto del 1881. Riassunti del Workshop "Dieci anni dopo il terremoto dell'Umbria-Marche: stato delle conoscenze sulla sismogenesi in Italia" Università di Camerino, pp 102-103

Poljak M, Zivcic M, Zupancic P (2000) The seismotectonic characteristics of Slovenia. Pure Appl Geophys 157:37-55. doi:10.1007/PL00001099

Pollitz FF, Burgmann R, Romanowicz B (1998) Viscosity of oceanic asthenosphere inferred from remote triggering of earthquakes. Science 280: 1245-1249. doi:10.1126/science.280.5367.1245

Postpischl D (ed) (1985) Catalogo dei terremoti italiani dall'anno 1000 al 1980. Quaderni della Ricerca Scientifica 114, 2B. Bologna, pp 242

Press WH, Flannery BP, Teukolsky SA, Vetterling WT (1992) Numerical recipes in FORTRAN 77: the art of scientific computing. Cambridge Univ. Press, Cambridge, pp 992

Rhoades TA, Evison FF (1979) Long range earthquake forecasting based on a single predictor. Geophys J R Astron Soc 59:43-56

Savage HM, Marone C (2007) Effects of shear velocity oscillations on stick-slip behavior in laboratory experiments. J Geophys Res 112:B02301. doi:10.1029/ 2005JB004238

Scholz CH, Gupta A (2000) Fault interactions and seismic hazard. J Geodynamics 29:459-467. doi:10.1016/ S0264-3707(99)00040-X
Shebalin NB, Karnik B, Hadzievki D (eds) (1974) UNDP/ENESCO Survey of the Balkan region. Catalogue of earthquakes Part I 1901-1970. Unesco, Paris

Tamburelli C, Babbucci D, Mantovani E (2000) Geodynamic implications of subduction related magmatism: insights from the Tyrrhenian-Apennines region. J Volcanol Geotherm Res 104:33-43. doi:10.1016/ S0377-0273(00)00198-0

Tondi E (2000) Geological analysis and seismic hazard in the Central Apennines. In: Cello G, Tondi E (eds), The resolution of geological analysis and models for earthquake faulting studies. J Geodynamics 29: 517-534

Viti M, D'Onza F, Mantovani E, Albarello D, Cenni N (2003) Post-seismic relaxation and earthquake triggering in the southern Adriatic region. Geophys J Int 153:645-657. doi:10.1046/j.1365-246X.2003. 01939.x

Viti M, De Luca J, Babbucci D, Mantovani E, Albarello D, D'Onza F (2004) Driving mechanism of tectonic activity in the northern Apennines: quantitative insights from numerical modelling. Tectonics 23:TC4003. doi:10.1029/2004TC001623

Viti M, Mantovani E, Babbucci D, Tamburelli C (2006) Quaternary geodynamics and deformation pattern in the Southern Apennines: implications for seismic activity. Boll Soc Geol Ital 125:273-291

Working Group CPTI (2004) Catalogo Parametrico dei terremoti Italiani, versione 2004 (CPTI04). INGV Bologna http://emidius.mi.ingv.it/CPTI/1-10 